\title{
Comparative Pathogenicity, Biocontrol Efficacy, and Multilocus Sequence Typing of Verticillium nonalfalfae from the Invasive Ailanthus altissima and Other Hosts
}

\author{
M. T. Kasson, D. P. G. Short, E. S. O’Neal, K. V. Subbarao, and D. D. Davis
}

First, third, and fifth authors: Department of Plant Pathology and Environmental Microbiology, The Pennsylvania State University, University Park 16802; and second and fourth authors, Department of Plant Pathology, University of California, Davis, 1636 E Alisal Street, Salinas 93905.

Current address of M. T. Kasson: Department of Plant Pathology, Physiology, and Weed Science, Virginia Tech University, Blacksburg. Accepted for publication 9 October 2013.

\begin{abstract}
Kasson, M. T., Short, D. P. G., O’Neal, E. S., Subbarao, K. V., and Davis, D. D. 2014. Comparative pathogenicity, biocontrol efficacy, and multilocus sequence typing of Verticillium nonalfalfae from the invasive Ailanthus altissima and other hosts. Phytopathology 104:282-292.

Verticillium wilt, caused by Verticillium nonalfalfae, is currently killing tens of thousands of highly invasive Ailanthus altissima trees within the forests in Pennsylvania, Ohio, and Virginia and is being considered as a biological control agent of Ailanthus. However, little is known about the pathogenicity and virulence of $V$. nonalfalfae isolates from other hosts on Ailanthus, or the genetic diversity among $V$. nonalfalfae from confirmed Ailanthus wilt epicenters and from locations and hosts not associated with Ailanthus wilt. Here, we compared the pathogenicity and virulence of several $V$. nonalfalfae and $V$. alfalfae isolates, evaluated the efficacy of the virulent $V$. nonalfalfae isolate VnAa140 as a biocontrol agent of Ailanthus in Pennsylvania, and performed multilocus sequence typing of $V$. nonalfalfae and $V$. alfalfae. Inoculations of seven $V$. nonalfalfae and $V$. alfalfae isolates from six plant hosts on healthy Ailanthus
\end{abstract}

ABSTRACT seedlings revealed that $V$. nonalfalfae isolates from hosts other than Ailanthus were not pathogenic on Ailanthus. In the field, 100 canopy Ailanthus trees were inoculated across 12 stands with VnAa140 from 2006 to 2009. By 2011, natural spread of the fungus had resulted in the mortality of $>14,000$ additional canopy Ailanthus trees, 10,000 to 15,000 Ailanthus sprouts, and nearly complete eradication of Ailanthus from several smaller inoculated stands, with the exception of a few scattered vegetative sprouts that persisted in the understory for several years before succumbing. All $V$. nonalfalfae isolates associated with the lethal wilt of Ailanthus, along with 18 additional isolates from 10 hosts, shared the same multilocus sequence type (MLST), MLST 1, whereas three V. nonalfalfae isolates from kiwifruit shared a second sequence type, MLST 2. All $V$. alfalfae isolates included in the study shared the same MLST and included the first example of $V$. alfalfae infecting a non-lucerne host. Our results indicate that $V$. nonalfalfae is host adapted and highly efficacious against Ailanthus and, thus, is a strong candidate for use as a biocontrol agent.

Additional keywords: tree-of-heaven, Verticillium albo-atrum.
Ailanthus altissima (Mill.) Swingle, commonly known as the tree-of-heaven or Ailanthus, is a highly invasive tree species first introduced into Philadelphia in 1784. Ailanthus is now present throughout most of the contiguous United States, mainly as an urban and roadside weed. The earliest report of Verticillium wilt of Ailanthus in the United States is from 1915 in Beaver County, PA (The Pennsylvania State University Plant Disease Clinic, unpublished archives). Other early Verticillium wilt epidemics of Ailanthus were reported in New York, Philadelphia, and Roanoke, VA in the late 1920s and early 1930s $(3,10,16)$. During the 1990s, extensive Verticillium wilt epidemics were observed on Ailanthus in New York on eastern Long Island and in the Hudson River Valley, and in Connecticut (7). Since 2003, unprecedented wilt and mortality of Ailanthus has nearly eliminated nearly 10,000 canopy Ailanthus trees in previously oak-dominated stands in south-central Pennsylvania (39). In 2010, another diseased Ailanthus stand was discovered in Washington County, PA,

Corresponding author: M. T. Kasson; E-mail address: mkasson@vt.edu

* The $\boldsymbol{e}$-Xtra logo stands for "electronic extra" and indicates that the online version contains two supplemental figures and two supplemental tables. Figures 2 and 4 appear in color online.

http://dx.doi.org/10.1094/PHYTO-06-13-0148-R

This article is in the public domain and not copyrightable. It may be freely reprinted with customary crediting of the source. The American Phytopathological Society, 2014. located $\approx 230 \mathrm{~km}$ west of the initial 2003 wilt epicenter and $35 \mathrm{~km}$ south of the 1915 location, containing several hundred infected Ailanthus. We determined the causal agent of these recent epidemics in Pennsylvania to be Verticillium nonalfalfae. This finding, along with recent reports of $V$. nonalfalfae killing Ailanthus in Virginia $(44,45)$ and Ohio (36), suggests that the lethal Ailanthus wilt caused by $V$. nonalfalfae is more widespread than previously considered and may implicate Ailanthus as an important host of $V$. nonalfalfae in the United States.

$V$. nonalfalfae is a vascular wilt pathogen of hops, solanaceous crops, spinach, and forest and shade trees in Canada, Japan, Slovenia, the United Kingdom, and the United States (19,20,32,40). Recent molecular systematics work has clarified its relationship to $V$. alfalfae and V. albo-atrum (20), which are morphologically indistinguishable. Early reports of Ailanthus infections by " $V$. albo-atrum" were likely caused by $V$. nonalfalfae, especially because $V$. albo-atrum sensu stricto has been reported only from potato (20).

Spatiotemporal migration patterns of invading Ailanthus in Pennsylvania suggest a recent increase of this tree in forested areas (23). Likewise, disease epidemics on Ailanthus appear to have intensified during recent decades $(7,39)$. Unlike Verticillium wilt epidemics in the forest setting, reports of lethal wilt epidemics in urban areas have been well documented for nearly a century. Even so, high natural mortality rates of Ailanthus within urban areas (31), as well as the presumed short life expectancy of Ailanthus (23), may have resulted in many Verticillium wilt 
epidemics being overlooked or mistaken for natural senescence or, more recently, herbicide damage along roadsides.

Even with significant mortality and rapid turnover, extant populations of Ailanthus persist throughout most of the conterminous United States and are especially abundant in the Mid-Atlantic region, where they have occurred for $\approx 200$ years $(1,23,27)$. The population structure of Ailanthus across the United States supports both East and West Coast introductions (1) and Ailanthus has been reported to be invasive in natural areas within at least 30 states (http://www.nps.gov/plants/alien/fact/aial1.htm). The development and utilization of $V$. nonalfalfae as a potential biological control of Ailanthus has been stymied, in part, by incomplete efficacy and host range testing (40) as well as unknown facets of host genetics $(1,8)$. Federal and state agencies are interested in using V. nonalfalfae to control Ailanthus both in forests and along transportation corridors, where conventional control measures have proven ineffective (M.T. Kasson, personal communications).

The objectives of this study were to (i) conduct comparative pathogenicity testing against A. altissima using a panel of $V$. alfalfae and $V$. nonalfalfae isolates from diverse hosts, (ii) evaluate efficacy of $V$. nonalfalfae isolate VnAa140 on canopy Ailanthus trees across various sites in Pennsylvania, (iii) assess longterm effects of $V$. nonalfalfae VnAa140 on Ailanthus regeneration in stands following death of Ailanthus canopy trees, and (iv) characterize the phylogenetic diversity, using a four-gene data set, of a collection of $V$. nonalfalfae isolates from Pennsylvania, Virginia, and Ohio and other isolates previously classified as $V$. albo-atrum.

\section{MATERIALS AND METHODS}

Inoculum preparation and culture maintenance. Verticillium cultures were maintained on plum extract agar (PEA), a semiselective media for Verticillium spp. (48), amended with streptomycin sulfate and neomycin sulfate, hereafter called $\mathrm{PEA}+\mathrm{SN}$ (39), in controlled environment chambers at $23^{\circ} \mathrm{C}$ for 3 weeks under a 12 -h photoperiod. Inoculum was prepared by adding 5 to $10 \mathrm{ml}$ of sterile distilled water to 3-week-old $V$. nonalfalfae isolate VnAa140 (formerly V. albo-atrum PSU140) cultures on PEA+SN and scraping the surface with a sterile glass rod. The resulting spore suspension was collected, vortexed, and passed through a sterile milk filter (KenAg, Ashland, OH) to remove mycelial fragments. Conidial concentrations were determined using a hemocytometer and adjusted to $1 \times 10^{7}$ conidia $\mathrm{ml}^{-1}$. Viability of conidia was evaluated by counting CFU from 10 -fold dilutions of suspensions on $\mathrm{PEA}+\mathrm{SN}$ plates. Inoculum was maintained at $4{ }^{\circ} \mathrm{C}$ until viability was confirmed. Only inoculum with $>80 \%$ viability was utilized.

For long-term maintenance of Verticillium strains, 10-ml scintillation vials containing a 1:1:1 sterile mix of potting soil/ peat moss/vermiculite were flooded with conidia harvested from 4-week-old cultures. After a 2-week incubation period, vials were stored at $4^{\circ} \mathrm{C}$. Preliminary laboratory studies had previously confirmed viability of isolates $>3$ years following inoculation and subsequent storage at $4^{\circ} \mathrm{C}$ (M. T. Kasson, unpublished data). Active cultures of VnAa140, the primary strain used in efficacy field studies, as well as other isolates were obtained by transferring inoculated soil from stored scintillation vials onto PEA+SN. To maintain pathogenicity of VnAa140 and other isolates, conidial suspensions were inoculated annually or biannually into several 1-month-old potted Ailanthus seedlings. Following symptom onset, cross-sections from symptomatic stems were plated on $\mathrm{PEA}+\mathrm{SN}$, and Verticillium spp. were reisolated and subcultured for use as inoculum.

Comparative pathogenicity testing of representative isolates of $V$. alfalfae and $V$. nonalfalfae on Ailanthus. Six isolates of $V$. nonalfalfae and one isolate of $V$. alfalfae were chosen for comparative pathogenicity testing on Ailanthus (Table 1). Inoculations of Ailanthus seedlings were conducted using a root-dip method (34). Roots of 3-week-old seedlings were rinsed, dipped into a $1 \times 10^{7} \mathrm{ml}^{-1}$ conidial suspension or water, and individually transplanted into tapered plastic containers $(3.8 \mathrm{~cm}$ top diameter by $20.3 \mathrm{~cm}$ deep) containing $\approx 140 \mathrm{~g}$ of premoistened Sunshine mix (Sun Gro Horticulture Canada Ltd., Vancouver, BC, Canada) and supplemented with Osmocote plant fertilizer (12:12:12, $\mathrm{N}-\mathrm{P}_{2} \mathrm{O}_{3}-\mathrm{K}_{2} \mathrm{O}$ slow-release; Scotts Miracle-Gro, Marysville, $\mathrm{OH}$ ). After transplanting, $1 \mathrm{ml}$ of additional inoculum was pipetted onto the base of each stem at the soil line. Disease progression was recorded weekly for 8 weeks, after which the experiment was terminated and indices developed by Qin et al. (34) utilized to quantify disease on a scale from 0 to 6 , where $0=$ no symptoms, $1=1$ to $25 \%$ vascular discoloration (VD), $2=26$ to $50 \% \mathrm{VD}, 3=$ 51 to $75 \% \mathrm{VD}, 4=76$ to $100 \% \mathrm{VD}, 5=4+$ wilt, and $6=5+$ mortality. Mean ratings were calculated based on average ratings of 10 plants per treatment, including the negative control. Isolates yielding a mean disease severity $\geq 2$ were considered pathogenic (34). All plants were destructively sampled and tissue samples exhibiting VD collected for reisolation.

Verticillium isolation and identifiers. Shoot tissues exhibiting $\mathrm{VD}$, or rachises or petioles from newly wilted leaves, were excised, surface disinfested in $95 \%$ ethanol, flamed, sectioned, and plated on PEA+SN. The plates were incubated on laboratory benches for 10 days and developing Verticillium colonies were plated onto fresh PEA+SN plates to determine species identities. Isolate identifiers were standardized as proposed by Bhat and Subbarao (4), where isolate identification is based on the Verticillium $\mathrm{sp} .(\mathrm{Vn}=V$. nonalfalfae $)$, binomial nomenclature of the infected host $(\mathrm{Aa}=A$. altissima $)$, and a unique numerical identifier (e.g., VnAa140) (Table 2).

Field study locations. The field study area spanned nine counties in south-central Pennsylvania, encompassing 14 forested stands on three state forests, one state game lands, one state park, and Army Corps of Engineering (ACOE) lands (Supplemental Figure 1). Tree species composition was typical of oak-dominated, mixed hardwood forests in southern Pennsylvania, including Ailanthus and numerous cohort species (39). In the northern region of the study area, additional cohort species included American elm, black cherry, and black walnut. Specific study plot locations are described in Supplemental Table 1. Stand histories for forests and individual locations were described by Kasson et al. (23).

Ailanthus canopy tree inoculations. Ailanthus was inoculated with $V$. nonalfalfae at 12 sites proximal to the area where Verticillium wilt of Ailanthus in Pennsylvania forests was first discovered (39). Correlations between Verticillium wilt disease development and geography, stem density, stem diameter, stand size, and spatial distribution of inoculated trees relative to each

TABLE 1. Pathogenicity ratings of different Verticillium isolates from different hosts on Ailanthus

\begin{tabular}{llc}
\hline Isolates & \multicolumn{1}{c}{ Origin } & Disease rating $^{\mathbf{z}}$ \\
\hline VnAa100 & Ailanthus altissima & 5.3 \\
VnAa140 & A. altissima & 5.1 \\
VaMs102 & Medicago sativa & 3.6 \\
VnCi21 & Ceanothus integerrimus & 1.0 \\
VnAc3 & Actinidia chinensis & 0.8 \\
VaSm621 & Solanum melongena & 0.4 \\
VnSt462 & S. tuberosum & 0.3 \\
Control & $\ldots$ & 0.0 \\
\hline
\end{tabular}

${ }^{\mathrm{z}}$ Mean vascular discoloration of 10 tested plants of Ailanthus altissima seed source HSAa23 from Penn State University campus. A 0 to 6 scale was adopted to assess disease severity, in which $0=$ no vascular discoloration, $1=1$ to $25 \%$ vascular area discolored (vad), $2=26$ to $50 \%$ vad, $3=51$ to $75 \%$ vad, $4=75$ to $100 \%$ vad, $5=4+$ wilting, and $6=5+$ associated mortality. Isolates causing a mean disease severity vascular area discolored with of $\geq 2$ on a certain host were considered pathogenic. 
other were assessed. Healthy Ailanthus stands near naturally infected stands were chosen for artificial inoculation to increase the likelihood of capturing similar host plant genotypes with comparable susceptibility to $V$. nonalfalfae infection.

In May 2006, a forest stand containing healthy Ailanthus trees atop Blue Mountain (BM) in Tuscarora State Forest was selected for inoculation. Twenty healthy canopy Ailanthus trees were clustered across four different sites separated by 0.3 to $2.0 \mathrm{~km}$ along a forest road. Five Ailanthus trees at each site were inoculated with isolate VnAa140 using a hypo-hatchet (OEM Fabricators Inc., Woodville, WI) that delivered $1 \mathrm{ml}$ of inoculum $\left(10^{7}\right.$ conidia $\mathrm{ml}^{-1}$ in sterile distilled water) per injection at three points on the stem base. A separate stand, located within the same forest, served as a control site, where trees were wounded with a surface-sterilized hatchet at three points on the stem base and treated with sterile distilled water (39). In May 2008, 10 additional stands, located across two state forests on state game lands and ACOE lands, were selected for inoculation studies. Five canopy Ailanthus trees were randomly selected for inoculation in five smaller stands and three larger stands, and 10 trees were selected in two additional larger stands. Trees were inoculated with VnAa140 as above. At two additional sites, five healthy canopy Ailanthus trees were selected as controls and wounded and treated as described above. In June 2009, a forested stand within the Canoe Creek State Park (CCSP) was selected to serve as a public demonstration site to illustrate the effectiveness of VnAa140 as a biocontrol agent of Ailanthus, wherein 20 healthy canopy Ailanthus trees were randomly selected and stem inoculated with VnAa140 using a hypo-hatchet.

Inoculated and control stands were evaluated biweekly, beginning 4 weeks after treatment (approximately early June) until late September to early October, except for CCSP, where evaluations began in late June. Evaluations were resumed the following spring and continued through the end of the second field season, except that stands BM and CCSP were evaluated biweekly for only one field season, and two of the 2008 stands (SGL1 and BSF2) were evaluated biweekly from May to October during a third field season. Of the 12 inoculated stands, five (BM, BSF2, CCSP, RLK1, and SGL1) were selected for longer-term studies and were evaluated annually until 2011, except for BM, which was evaluated every other year through 2011.

Disease severity was assessed using an ordinal rating system, where 1 = asymptomatic foliage, 2 = general marginal leaf chlorosis or necrosis, $3=$ presence of wilt, and $4=$ death (40). The area under the disease progress curve (AUDPC) was calculated for each plot to compare disease progression among species

TABLE 2. Verticillium isolates used for molecular studies

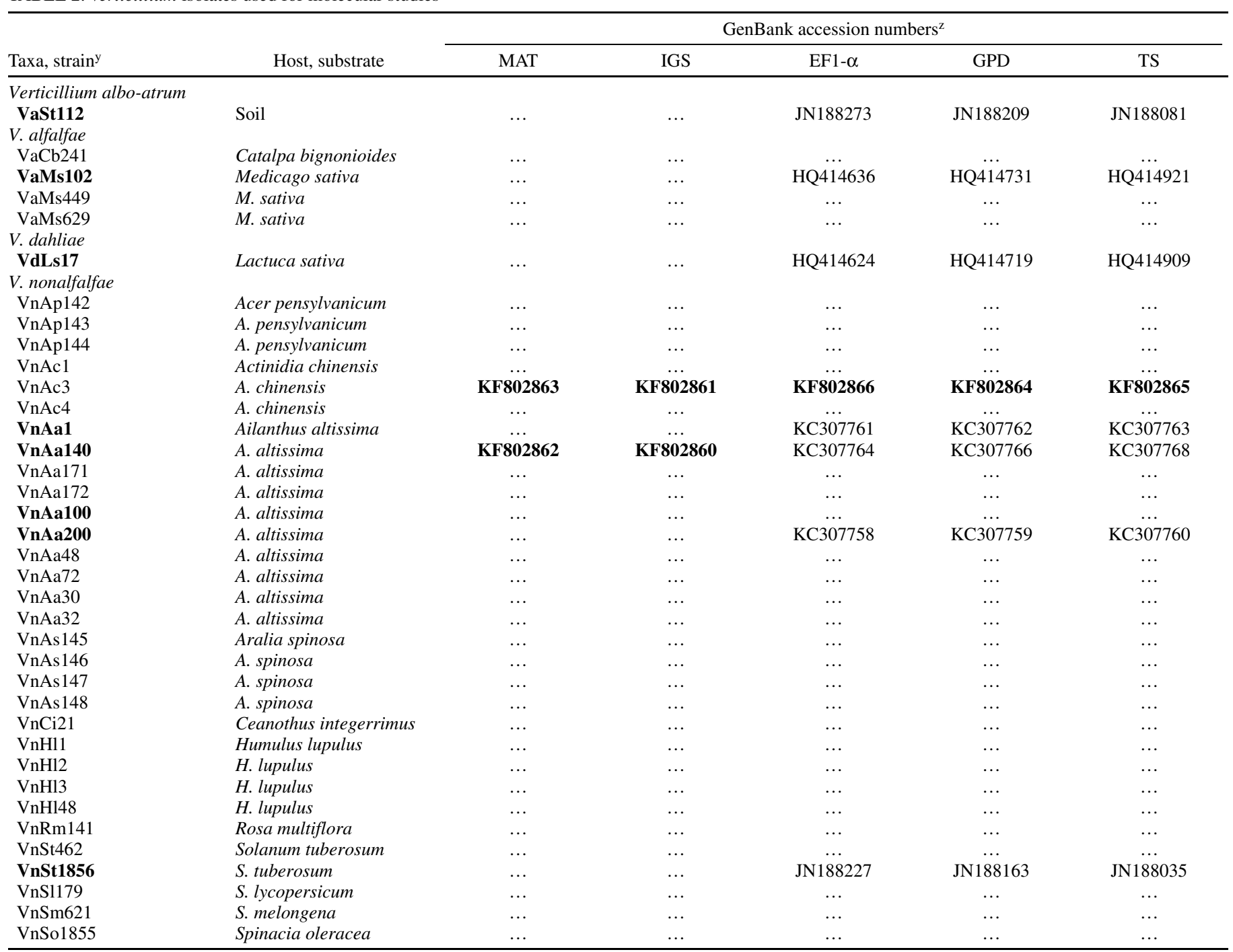

y Taxa and strain identifiers used in this study. Strain identifiers in bold indicate isolates previously confirmed with DNA sequencing. See corresponding GenBank accession numbers in three right-most columns.

${ }^{\mathrm{z}}$ IGS = intergenic spacer, EF-1 $\alpha=$ elongation factor $1 \alpha, \mathrm{GPD}=$ glyceraldehyde-3-phosphate dehydrogenase, and TS = tryptophan synthase. GenBank accession numbers in bold denote representative sequences for $V$. nonalfalfae deposited as part of this study. 
and treatments (39). Tree diameters of inoculated and control Ailanthus were averaged across each stand as well as placed into 5 -cm increment designations, regardless of stand location (data not shown), to determine the relationships between stem diameter and disease progression.

Long-term effects of $V$. nonalfalfae VnAa140 on Ailanthus regeneration survival and establishment. In 2011, five stands (BM, BSF2, CCSP, RLK1, and SGL1) that had been previously inoculated with $V$. nonalfalfae VnAa140 and contained numerous dead and dying Ailanthus canopy trees were selected for regeneration studies. Stand BM had been inoculated in 2006 and the remaining stands were inoculated in 2008 to 2009 . One eastwest transect was established within the infected areas of stands in BSF2, CCSP, RLK1, and SGL1. Two east-west transects were established in stand BM, because diseased Ailanthus trees were more widely spaced, with four separate disease foci. Because most Ailanthus stands had an east-west orientation and were typically located on south-facing slopes, east-west transects encompassed the widest area of the diseased stands and therefore included the maximum number of Ailanthus stems.

Within each stand, the transect line was established through the main Verticillium wilt infection center and extended $30 \mathrm{~m}$ beyond the outer edge of the infection center (Fig. 1). Six 4.05- $\mathrm{m}^{2}$ circular regeneration subplots were established in three pairs in opposing directions, including two subplots in the approximate center of each stand, where the Ailanthus stems had been originally inoculated; two subplots $10 \mathrm{~m}$ inside the advancing edge of disease epicenter; and two subplots $30 \mathrm{~m}$ beyond the advancing edge (outside) of the diseased stand (into the asymptomatic portion of the stand) (Fig. 1). Outside subplots served as pretreatment controls, because these areas remained undisturbed at the time of observations and were basically unaffected by canopy openings $30 \mathrm{~m}$ distant. Numbers, heights, and disease ratings ( 0 to 2) of Ailanthus regeneration were recorded using an ordinal rating system, as described by Schall and Davis (40). Ailanthus roots were excavated to determine whether regeneration had occurred from seed or root sprout. Likewise, numbers and disease ratings (if applicable) of native woody species were also recorded for each sampled subplot.

Statistical analyses of field data. Analysis of variance (ANOVA) and Tukey's mean comparisons were used to evaluate significant differences among AUDPC data, mean diameters of Ailanthus among inoculation sites, and seedling counts and heights in regeneration subplots. All analyses were conducted using Minitab 16.1.0 (Minitab Inc., State College, PA).

DNA extraction and molecular characterizations. Total genomic DNA was extracted from lyophilized mycelial plugs harvested from potato dextrose broth (BD, Franklin Lakes, NJ) using a Wizard genomic DNA purification protocol (Promega Corp., Madison, WI). For multilocus sequence typing and phylogenetic analyses, previously published protocols were used (21, $34)$ to amplify the following loci: the protein-coding genes elongation factor $1 \alpha($ EF- $1 \alpha)$, glyceraldehyde-3-phosphate dehydrogenase (GPD), and tryptophan synthase (TS); and a portion of the intergenic spacer (IGS) region of the ribosomal DNA (rDNA) repeat. Polymerase chain reaction (PCR) assays targeting MAT11-1 and MAT1-2-1 were also used to determine mating types of 36 isolates, as previously described (21).

Sanger sequencing using the forward and reverse PCR primers was performed at the Penn State Genomics Core Facility, University Park, PA, on an ABI 3730 XL automated DNA sequencer (Applied Biosystems, Carlsbad, CA). Sequencher (version 5.1; GeneCodes Corporation, Ann Arbor, MI) was used to edit the raw chromatograms. Edited sequences were used as BLAST queries against the National Center for Biotechnology Information (NCBI) GenBank database for preliminary identification.

A concatenated four-locus alignment was generated using CLUSTAL-W (http://www.genome.jp/tools/clustalw) followed by manual improvement. Separate partitions were created for each gene to permit analyses for both individual genes and the combined dataset. Maximum likelihood (ML) analyses were conducted using MEGA 5.1 (49). ML bootstrap analyses of the individual and combined dataset were run on the CIPRES Science Gateway (http://www.phylo.org/portal2/login) using GARLI ver. 1.0 (54) on the TeraGrid. Sequence data from NCBI GenBank for V. dahliae and V. albo-atrum were used as outgroups.

To verify species identity, DNA from Verticillium isolates from Actinidia were used as templates in a V. albo-atrum-V. alfalfae-V. nonalfalfae multiplex PCR assay and a $V$. nonalfalfae simplex PCR, as previously described (22). For the multiplex and simplex PCRs, the reference isolates PD 338 ( $V$. alfalfae), PD 745 (V. nonalfalfae), and PD 592 ( $V$. nonalfalfae) were used as positive controls.

\section{RESULTS}

Comparative pathogenicity testing. Comparative pathogenicity testing revealed differential responses of the Verticillium spp. and isolates on Ailanthus. Of the seven isolates tested, two isolates of $V$. nonalfalfae from Ailanthus and one isolate of $V$. alfalfae from alfalfa were pathogenic (average disease score $\geq 2$ ) on Ailanthus. V. alfalfae isolate VaMs102 resulted only in VD but the two $V$. nonalfalfae isolates from Ailanthus resulted in acute wilt in all plants and some mortality by 8 weeks postinoculation (Table 1). V. nonalfalfae isolates from deerbrush, eggplant, kiwifruit, and potato were not pathogenic on Ailanthus, although low levels $(<25 \%)$ of VD were observed in some individuals from each isolate (Table 1).

Ailanthus canopy tree inoculations. Twenty canopy Ailanthus trees within stand BM inoculated with VnAa140 developed wilt symptoms and yellow to yellowish-brown VD within 3 to 4 weeks, followed by occasional necrosis of previously wilted leaves prior to senescence, premature defoliation, and mortality (Fig. 2), similar to symptoms observed in naturally infected Ailanthus

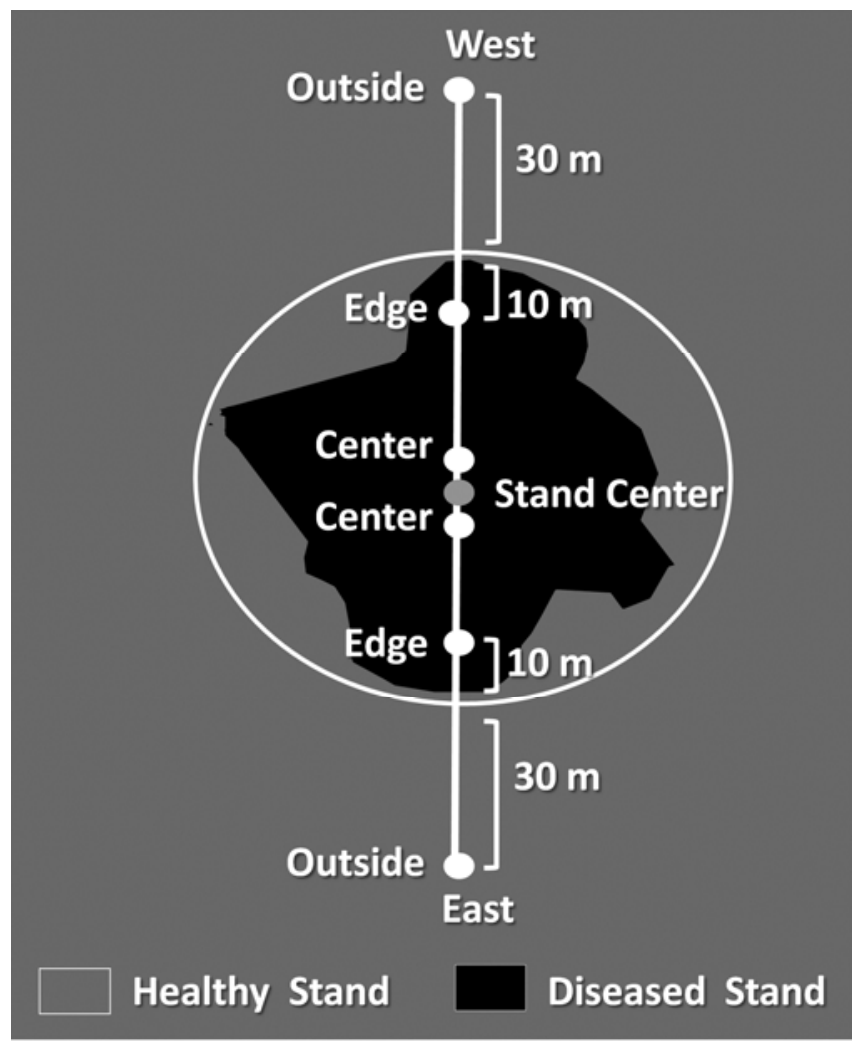

Fig. 1. Schematic diagram illustrating the location of regeneration subplots within diseased Ailanthus stands. 
(39). By 12 months post-inoculation (MPI), all inoculated trees were dead. The pathogen spread from the original inoculation point, causing symptoms on 800 formerly healthy Ailanthus trees (Figs. 3 and 4), a majority of which eventually died, except for a few infected trees that sprouted along the main stem (Figs. 2D and 4C) that also ultimately wilted and died. By 36 MPI, there were 2,663 dead and dying Ailanthus stems surrounding the point of inoculation (Fig. 3). By the final survey, conducted 63 MPI in August 2011, a total of 8,897 canopy Ailanthus trees had succumbed as a result of natural spread of this pathogen from the 20 inoculated trees (Fig. 3).

The 10 Ailanthus stands that had been inoculated with VnAa140 in 2008 were of various sizes, ages, and stem densities (23). Inoculated stands exhibited first disease symptoms $\approx 3$ weeks post-inoculation (WPI), with the exception of site RLK3, which exhibited wilt symptoms at 5 WPI. The control plots (BSF3 and MSF2) remained asymptomatic for the duration of the experiment.

Mean AUDPC values were significantly greater for inoculated plots than noninoculated controls $(P=0.000)$ (Table 3$)$. Mean AUDPC values also differed significantly among the 10 inoculated sites, indicating that disease progression differed among sites (Table 3). Stands BSF1 and SGL1 had the highest mean AUDPC (247.0 and 242.0, respectively) at 69 WPI. These two stands had significantly greater AUDPC values than RLK3 (207.8) and MSF1 (201.2) (Table 3). Mean AUDPC for BSF2 (236.8) and MSF5 (239.4) were also significantly different from the AUDPC values for MSF1 (201.2) $(P=0.024$ and 0.049, respectively) (Table 3 ).
Significant differences in mean stem diameters also occurred among stands. Mean stem diameter at RLK3 $(31.8 \mathrm{~cm})$ was significantly greater than at SGL1 $(11.6 \mathrm{~cm}, P=0.000)$, MSF3 $(13.2 \mathrm{~cm}, P=0.006)$, MSF4 $(15.5 \mathrm{~cm}, P=0.027)$, and RLK2

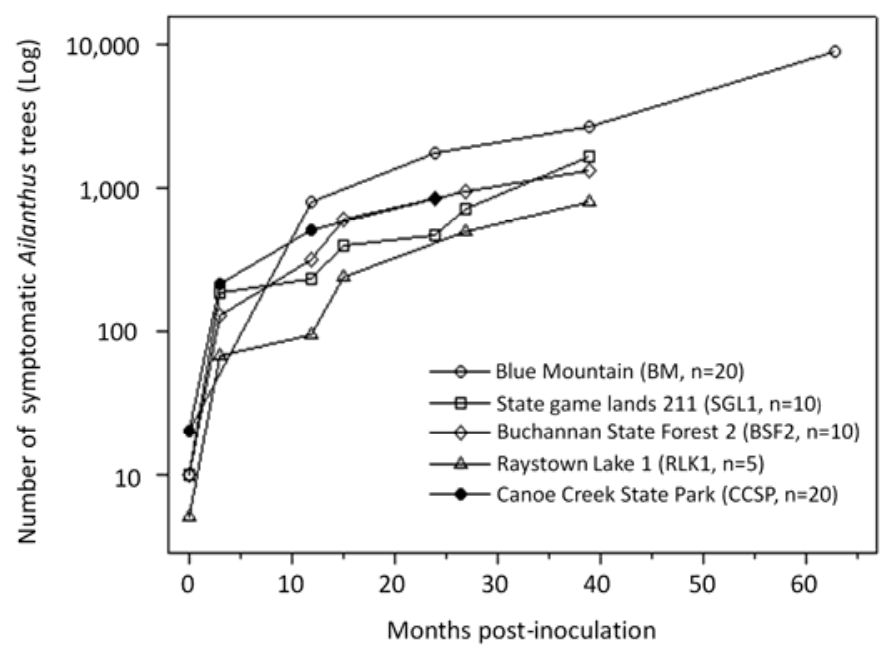

Fig. 3. Disease progression of Verticillium nonalfalfae isolate VnAa140 across five artificially inoculated Ailanthus stands in south-central Pennsylvania during 2006 to 2011. Inoculation dates were: BM (May 2006); SGL1, BSF2, and RLK1 (May 2008); and CCSP (June 2009). Observations were made in early growing season (May), late growing season (July to August), or both and include $3,12,15,24,27,36$, and 63 months post-inoculation.
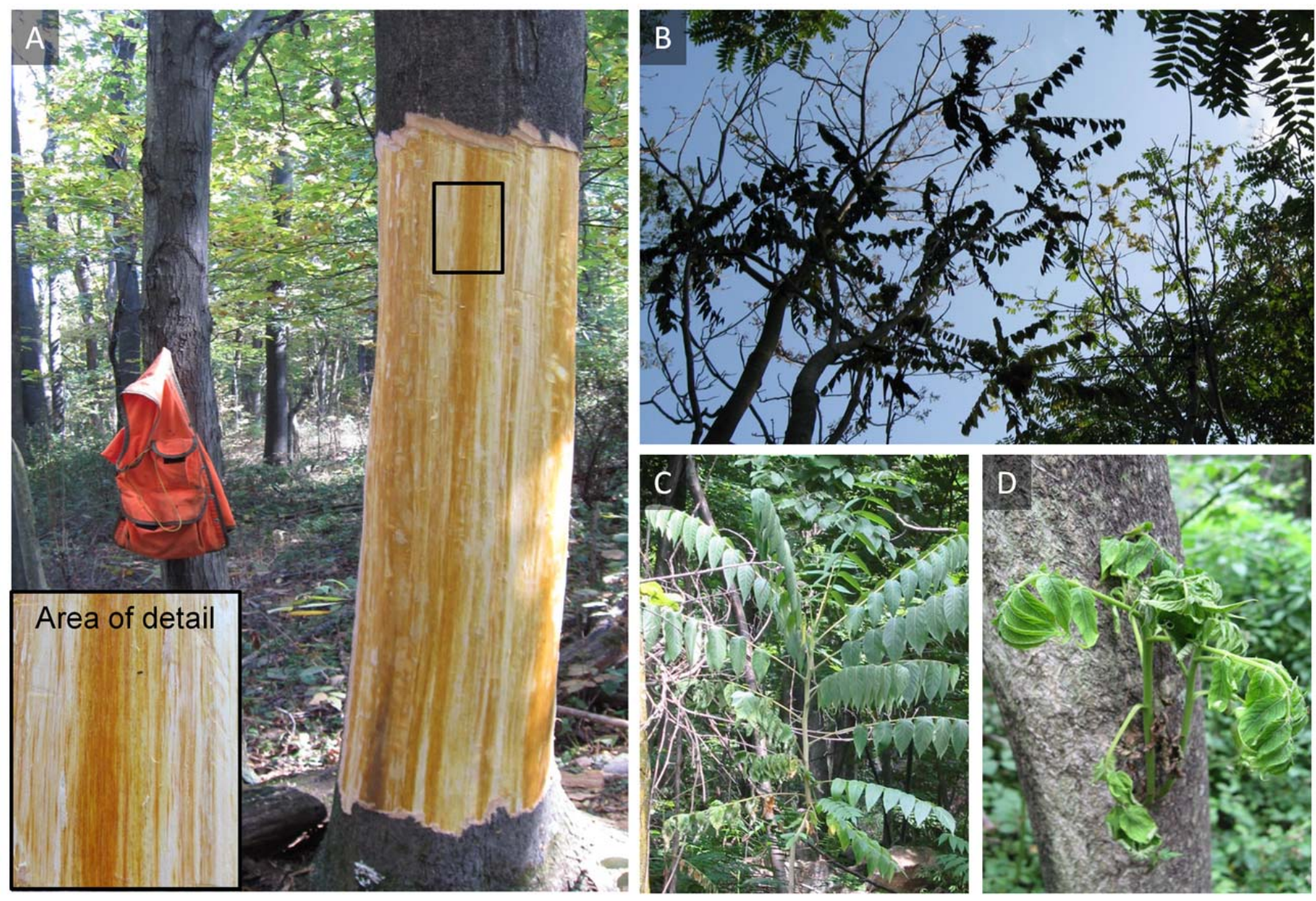

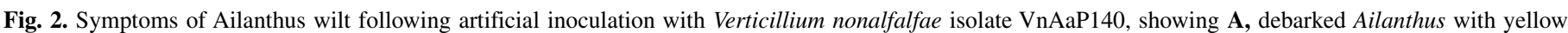

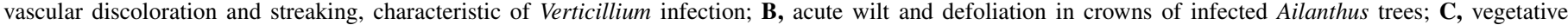

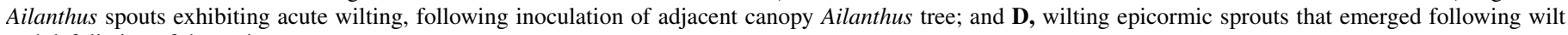
and defoliation of the main crown. 
(16.4 cm, $P=0.048$ ) (Table 3 ). In general, stands with smallerdiameter Ailanthus trees had greater AUDPC values (Table 3). For example, trees in the $15-\mathrm{cm}$ class across all locations had an average AUDPC value of 248.7, which is significantly greater $(P<0.001)$ than the AUDPC values for trees in the $45-\mathrm{cm}$ diameter class (195.6) However, tree diameter was not significantly related to the AUDPC values at MSF1 (Table 3).

In all four inoculated stands $<2$ ha in size and in one of two stands that were 2 to 8 ha and inoculated with VnAa140 in 2008, $100 \%$ mortality of overstory Ailanthus occurred. Disease or mortality of overstory Ailanthus trees did not occur in the watertreated control stands. Therefore, long-term stand data were collected only from the three larger remaining stands inoculated in 2008 (BSF2, RLK1, and SGL1). In stand BSF2, 10 trees were originally inoculated with VnAa140; at 12 MPI, 309 Ailanthus trees were symptomatic; at $39 \mathrm{MPI}, \approx 1,300$ Ailanthus stems were symptomatic (Fig. 3). In stand RLK1, 5 trees were inoculated with VnAa140; at 12 WPI, 93 Ailanthus stems were symptomatic; at 39 MPI, >790 Ailanthus trees had Verticillium wilt at this site and were either dead or dying (Fig. 3). At SGL1, 10 trees were inoculated with VnAa140; at $12 \mathrm{MPI}, 231$ stems were symptomatic; at 39 MPI, 1,646 stems were symptomatic. However, unlike BSF2 and RLK1, the number of symptomatic Ailanthus stems in SGL1 increased nearly fourfold between 24 to 39 MPI, from 464 to 1,646 stems (Fig. 3).
In June 2009, 20 canopy Ailanthus trees were inoculated at CCSP in Blair County. The initial disease symptoms appeared $<2$ weeks after inoculation, and were similar to those observed in other inoculated stands (Fig. 2). At 12 MPI, there were 503

TABLE 3. Mean area under the disease progress curve (AUDPC) values 69 weeks post-inoculation and mean diameter at breast height $(\mathrm{DBH})$ for 2008 field-inoculated Ailanthus ${ }^{\mathrm{z}}$

\begin{tabular}{lll}
\hline Plot & AUDPC & DBH \\
\hline BSF1 & $247.0 \mathrm{a}$ & $19.7 \mathrm{abcd}$ \\
SGL1 & $242.0 \mathrm{a}$ & $11.6 \mathrm{~d}$ \\
MSF5 & $239.4 \mathrm{ab}$ & $21.8 \mathrm{abcd}$ \\
BSF2 & $236.8 \mathrm{ab}$ & $20.1 \mathrm{abcd}$ \\
RLK2 & $234.8 \mathrm{abc}$ & $16.4 \mathrm{bcd}$ \\
MSF4 & $230.6 \mathrm{abc}$ & $15.5 \mathrm{bcd}$ \\
RLK1 & $229.6 \mathrm{abc}$ & $26.4 \mathrm{abc}$ \\
MSF3 & $214.6 \mathrm{abc}$ & $13.2 \mathrm{~cd}$ \\
RLK3 & $207.8 \mathrm{bc}$ & $31.8 \mathrm{a}$ \\
MSF1 & $201.2 \mathrm{c}$ & $20.8 \mathrm{abcd}$ \\
BSF3-Control & $69.0 \mathrm{~d}$ & $30.5 \mathrm{ab}$ \\
MSF2-Control & $69.0 \mathrm{~d}$ & $21.4 \mathrm{abcd}$ \\
\hline
\end{tabular}

${ }^{2}$ AUDPC and DBH values followed by the same letter within a given column are not significantly different according to Tukey's pairwise comparisons $(P=0.001)$. Controls include Ailanthus injected with sterile distilled water at two separate locations.
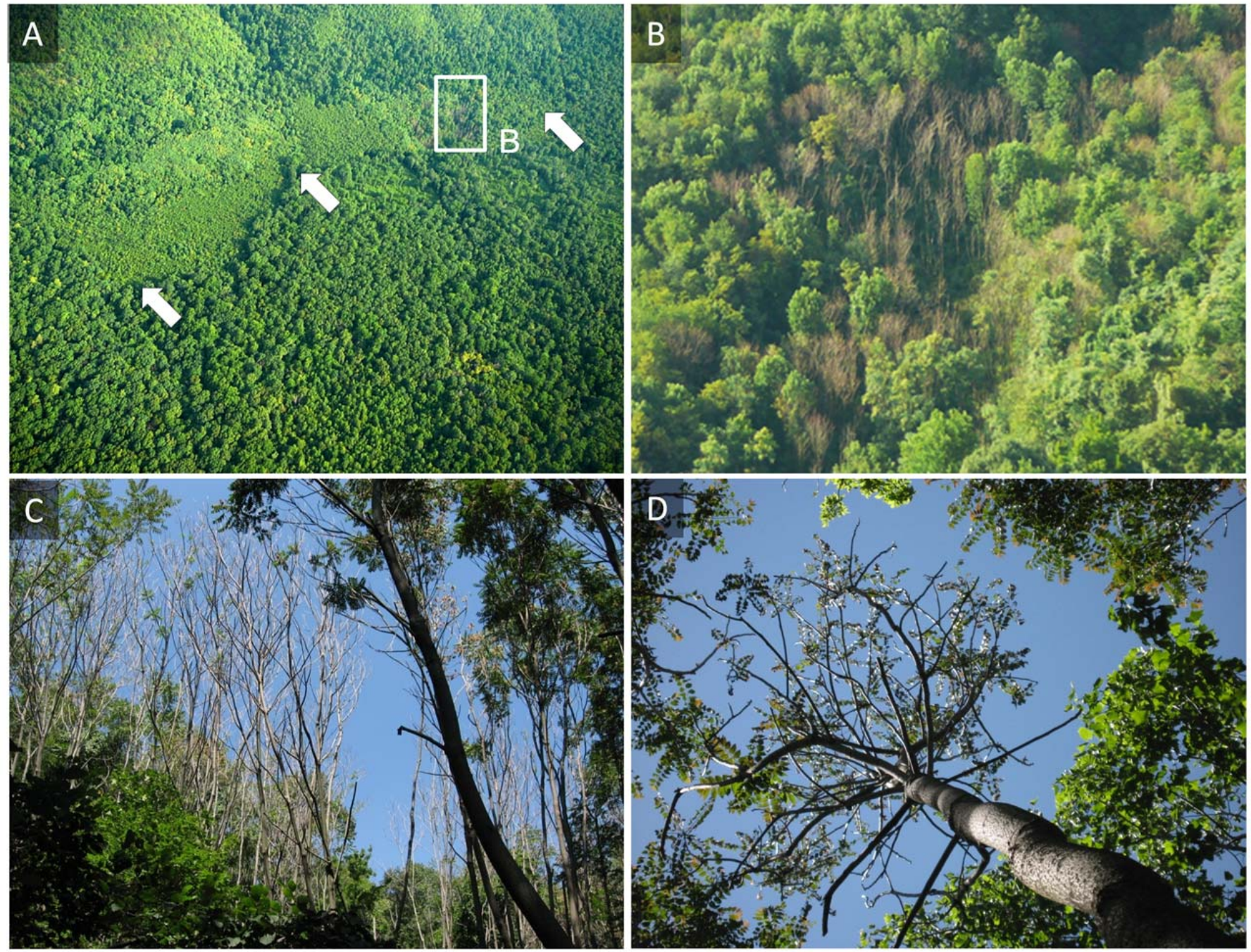

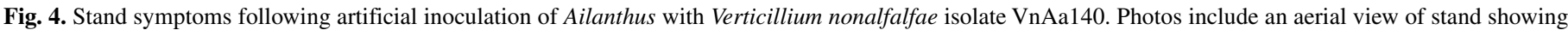

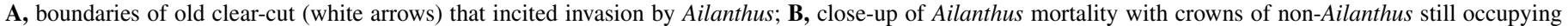

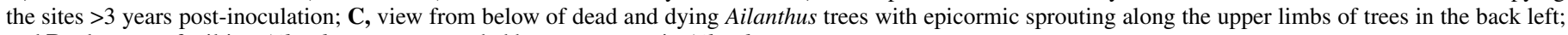
and D, close-up of wilting Ailanthus tree surrounded by asymptomatic Ailanthus. 
diseased stems at this site; at 24 MPI, 841 stems were symptomatic (Fig. 3).

From the initial focus of 100 Ailanthus trees inoculated with VnAa140 across 12 stands in south-central Pennsylvania from 2006 to 2009, natural spread of the pathogen resulted in mortality of 14,162 canopy stems (Fig. 3).

Effect of VnAa140 on site recolonization by Ailanthus. After inoculation of Ailanthus canopy trees with VnAa140, some Ailanthus seedlings or sprouts persisted within all inoculated stands for several years but only vegetative root sprouts were found within the regeneration plots. Ailanthus regeneration occurred in 20 of $364-\mathrm{m}^{2}$ test subplots across five forested stands (Fig. 5A). On average, 12 Ailanthus sprouts were found across the 20 positive subplots (range $=1$ to 54 ). However, differences were observed in the number of Ailanthus observed among the three subplot locations within the larger stands. Ailanthus was observed in only 4 of 12 of center subplots, whereas Ailanthus was observed in 9 of 12 of edge subplots and 7 of 12 of outside subplots (Fig. 5A). In terms of total number of trees, 16 Ailanthus occurred within center subplots, whereas 163 and 74 trees were observed in edge and outside subplots, respectively (Fig. 5C).
On average, three diseased or dead sprouts per plot were found across 4 of 12 edge plots but in none of the center and outside subplots. In terms of total number of Ailanthus, 13 of 163 Ailanthus were symptomatic or dead within edge subplots (Fig. $5 \mathrm{C})$. Total estimated density for diseased sprouts across all stands was $\approx 440$ diseased sprouts/ha across all edge plots. In total, some 10,000 to 15,000 diseased Ailanthus sprouts were estimated to occur across all plots.

To examine the effect of VnAa140 on Ailanthus reestablishment, mean heights of Ailanthus in regeneration plots were compared in the BM regeneration plots, due to the presence of asymptomatic Ailanthus trees (172 of 253) in 9 of the 12 subplots. Average heights of Ailanthus were significantly greater in the center subplots $(21.3 \mathrm{~cm})$ than in the edge $(7.5 \mathrm{~cm})$ and outside subplots $(8.2 \mathrm{~cm})(P=0.000)$ (Fig. 5D).

Total numbers of native perennial woody plant species were also recorded across the five long-term study areas in all regeneration subplots. In total, 183 non-Ailanthus native seedlings and saplings were observed in 23 of 36 subplots (Fig. 5A). On average, 5 plants/plot (range $=1$ to 40 ) were observed within the subplots containing native species (Fig. 5). The most abundant
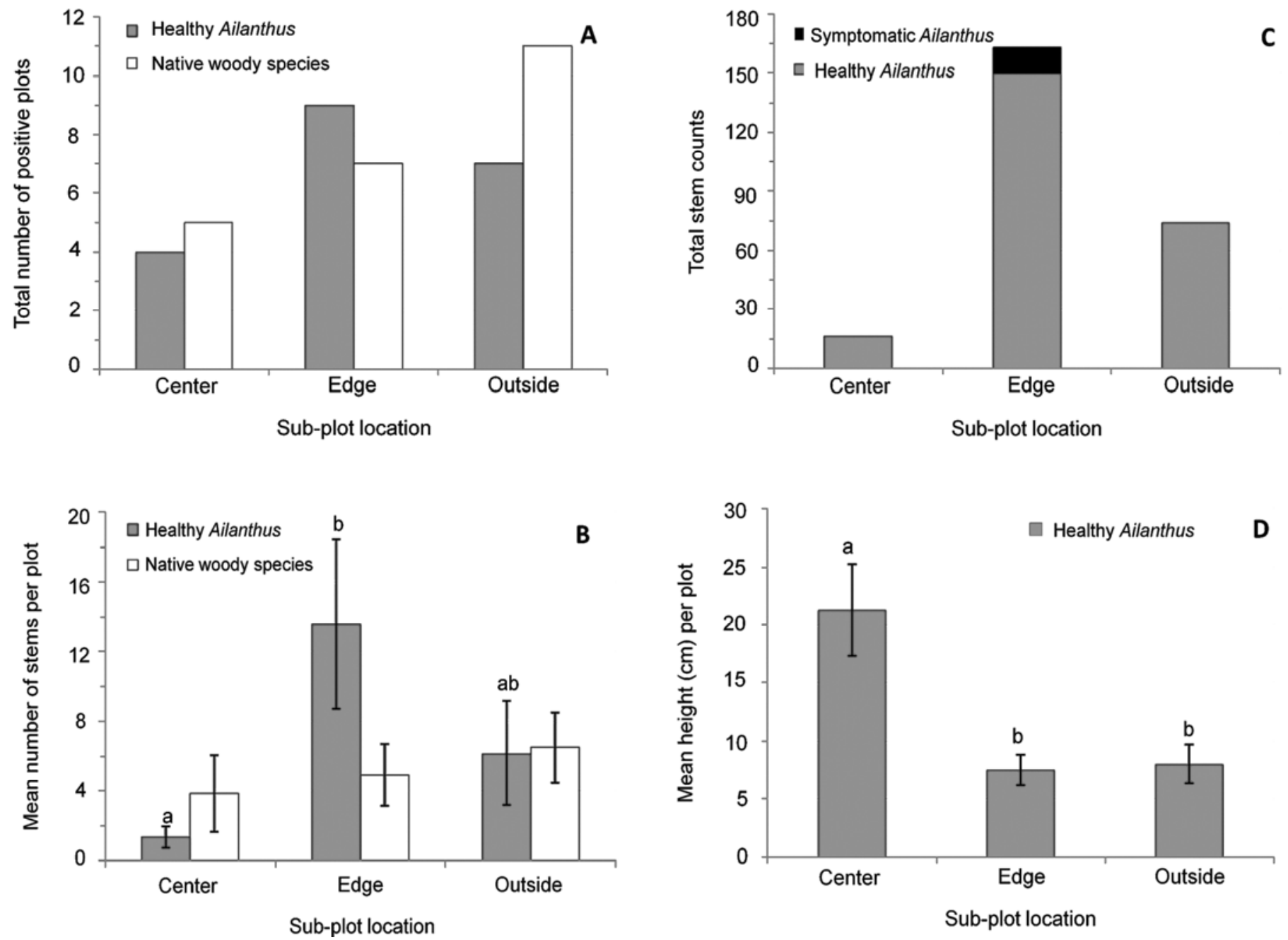

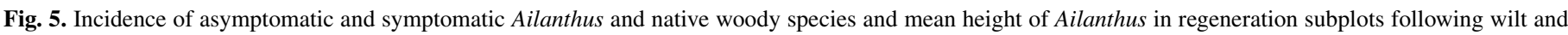

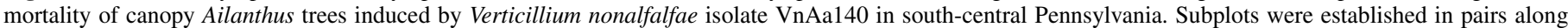

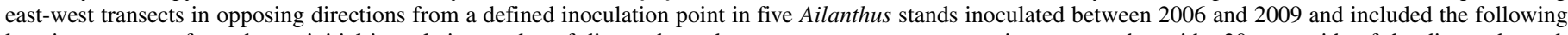

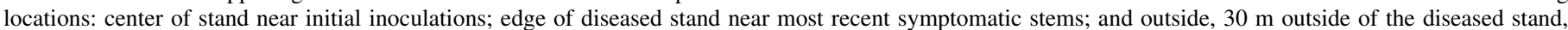

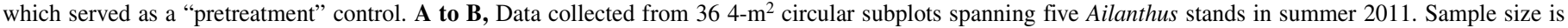

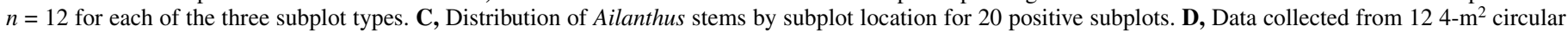

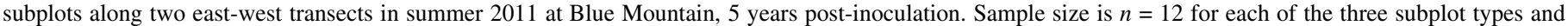

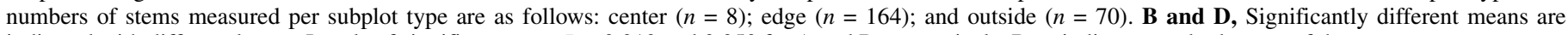
indicated with different letters. Levels of significance are $P<0.010$ and 0.050 for A and B, respectively. Bars indicate standard errors of the means. 
tree species were American elm (Ulmus americana L.), red maple (Acer rubrum L.), sugar maple (A. saccharum Marsh.), and black cherry (Prunus serotina Ehrh.). Poison-ivy seedlings (Toxicodendron radicans (L.) Kuntze) were also abundant but were restricted to location CCSP. ANOVA revealed no significant differences in the mean number of native plants among center (4 plants/subplot), edge (5 plants/subplot), and outside (7 plants/ subplot) subplots $(P=0.644)$ (Fig. 5B). Verticillium wilt symptoms were not observed in native regeneration, although plants were not destructively sampled to evaluate VD.

Multilocus sequence typing and species and mating type identification using PCR. Sequence data for 37 taxa were obtained from portions of three nuclear protein coding genes (EF$1 \alpha$, GPD, and TS) as well as a portion of the IGS rDNA region in the study. Representative nucleotide sequences for previously uncharacterized lineages and gene regions, denoted in Table 2, were deposited in GenBank (accession numbers KF802860 to KF802866). Ten isolates from A. altissima and 18 other nonlucerne isolates previously identified as " $V$. albo-atrum" resolved to $V$. nonalfalfae and one previously designated " $V$. albo-atrum" isolate $\mathrm{VaCb} 241$, from Catalpa bignonioides, aligned with three $V$. alfalfae strains from alfalfa (Fig. 6). The $28 \mathrm{~V}$. nonalfalfae isolates formed a clonal group along with holotype $V$. nonalfalfae isolate PD 592 from potato and are hereafter designated collectively as multilocus sequence type (MLST) 1 (Fig. 6). Isolates from gold kiwifruit (Actinidia chinensis; 2) were identified as $V$. nonalfalfae in a multiplex PCR but formed a distinct intraspecific group and are hereafter designated as MLST 2 (Fig. 6). The $V$. albo-atrum-V. alfalfae-V. nonalfalfae multiplex PCR and $V$. nonalfalfae simplex PCR (22) identified all isolates from the genus Actinidia as members of V. nonalfalfae (data not shown).

Thirty-six isolates were screened for mating type. $V$. nonalfalfae isolates, which included both MLST 1 and 2, were exclusively MAT1-2-1, whereas $V$. alfalfae isolates were exclusively MAT1-1-1 (Supplemental Figure 2). All amplicons were sequenced and identified by a BLASTn search using GenBank. All MAT1-1-1 amplicons showed 94\% identity with GenBank accession AB505215 from $V$. dahliae whereas all MAT1-2-1 amplicons showed 96\% identity with GenBank accession AB505214 from V. dahliae.

\section{DISCUSSION}

The objectives of the current study were to compare the pathogenicity of Verticillium isolates from six plant species against Ailanthus altissima, evaluate the biocontrol efficacy of $V$. nonalfalfae isolate VnAa140 on Ailanthus canopy trees and shoot regeneration under various field conditions, and investigate the multilocus phylogenetic diversity of $V$. nonalfalfae isolates from lethal Ailanthus wilt epicenters in three states and from environments not associated with Ailanthus wilt.

Comparative pathogenicity testing revealed varying responses of six $V$. nonalfalfae and one $V$. alfalfae against a susceptible Ailanthus seed source. Isolates of $V$. nonalfalfae from deerbrush, eggplant, kiwifruit, and potato were nonpathogenic on Ailanthus, suggesting possible host adaptation in VnAa140 and VnAa100, both of which showed high virulence against Ailanthus. These results were independently confirmed for all Ailanthus isolates from Virginia and VnAa140 (45). Even though significant VD was observed on Ailanthus plants inoculated with $V$. alfalfae isolate VnMs102, the isolate did not induce wilting or mortality. VD alone may not be harmful to the host (37), because xylem occlusion can occur without inducing wilt or mortality, as observed previously for $V$. dahliae in Ailanthus (23). These effects appear to be transitory, following which the symptomatic plants may resume normal growth.

In south-central Pennsylvania and central Virginia, lethal wilt of Ailanthus has reached epidemic proportions (45), while few native flora have been affected. Naturally occurring $V$. nonalfalfae infections in Pennsylvania, along with artificial inoculations conducted from 2006 to 2009, have resulted in $>22,000$ dead canopy Ailanthus trees. Within one regions of Pennsylvania, injection of $V$. nonalfalfae inoculum into 100 trees eventually resulted in $>14,000$ dead Ailanthus as the pathogen spread from the inoculated trees to adjacent healthy Ailanthus trees during 2006 to 2011. Root sprouts, established after the death of overstory canopy Ailanthus, were also infected by $V$. nonalfalfae and accounted for an additional 10,000 to 15,000 dead Ailanthus. Furthermore, $V$. nonalfalfae was isolated from several naturally infected symptomatic striped maple (Acer pensylvanicum L.), devil's walkingstick (Aralia spinosa L.), and one mutliflora rose plant (Rosa multiflora Thunb.) but represented only a few individuals as compared to a few thousand otherwise healthy stems. Thus, VnAa140 appears to be host-adapted to Ailanthus.

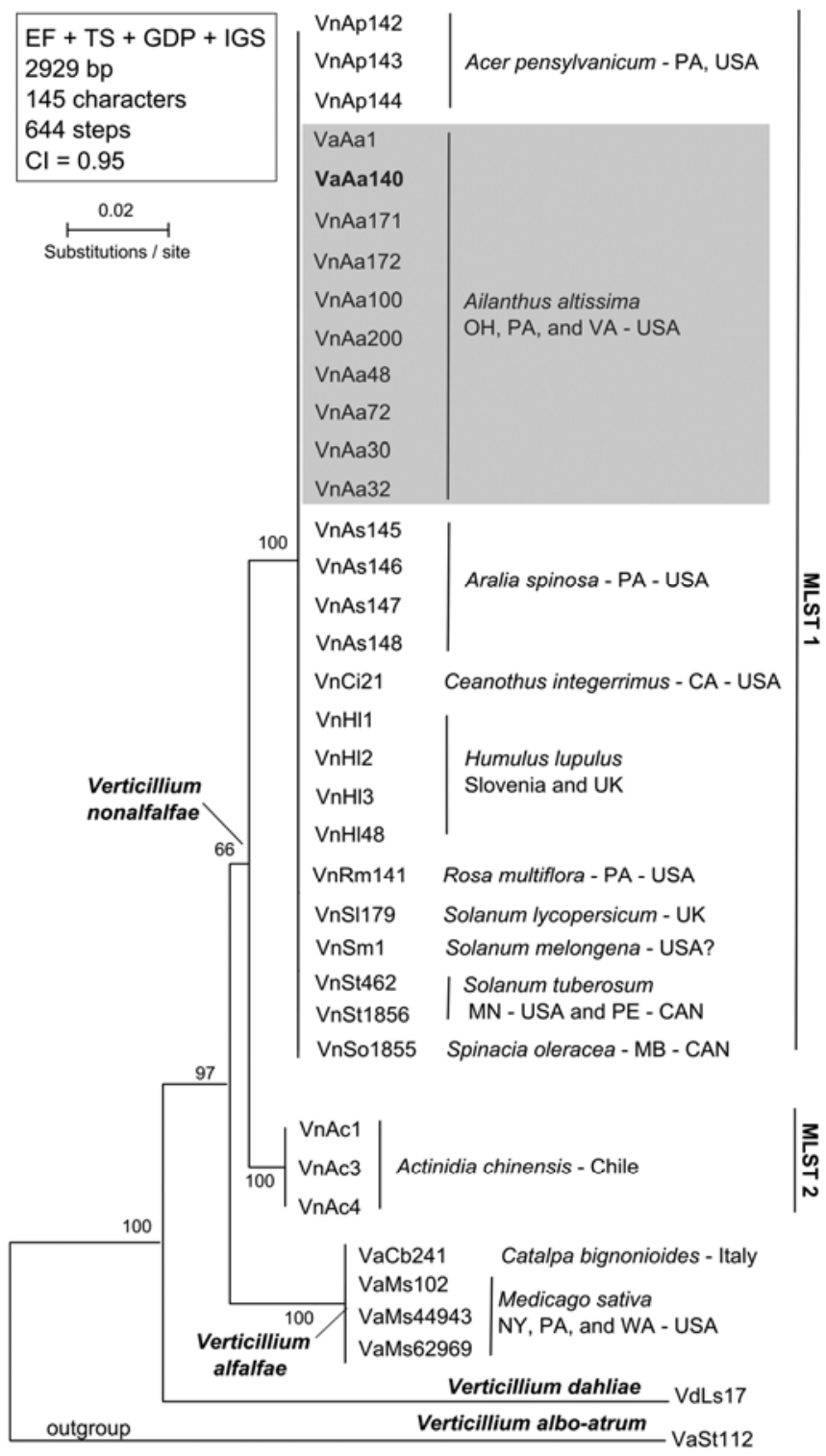

Fig. 6. Molecular phylogeny of phytopathogenic Verticillium sp. from Ailanthus (gray box) and other perennial woody and crop hosts inferred from partial elongation factor 1- $\alpha(\mathrm{EF})$, glyceraldehyde-3-phosphate dehydrogenase (GPD), tryptophan synthase (TS), and intergenic spacer (IGS) sequences. Verticillium albo-atrum isolate VaSt112 was used to root the tree. The maximum likelihood (ML) tree was inferred from 2,929 nucleotide characters, of which 145 were shared derived characters. ML bootstrap values are indicated at nodes based on a 1,000 pseudoreplicates of the data. MLST = multilocus sequence type. 
$V$. nonalfalfae has been reported to cause disease in only two tree species in the forest setting-a Ceanothus sp. in California (13) and yellow-poplar in Delaware (28) - although infections of various woody hosts in urban environments by " $V$. albo-atrum" likely caused by $V$. nonalfalfae have been reported $(10,18,19,32)$. Additional studies are needed to validate these earlier reports because more recent investigations by Schall and Davis (40) invalidated yellow-poplar and other previously designated "susceptible" species as hosts for $V$. nonalfalfae. Our recent discovery of $V$. nonalfalfae in a forest setting $<12 \mathrm{~km}$ from an earlier reported infection suggests that $V$. nonalfalfae is pervasive on Ailanthus in western Pennsylvania. In addition, because $V$. nonalfalfae has now been confirmed killing Ailanthus in at least nine locations spanning three states $(36,39,44,45)$, Ailanthus and $V$. nonalfalfae may now be occupying the same ecological niches and Verticillium wilt of Ailanthus may become more common as environmental conditions favor infection.

Few potential Ailanthus biocontrol candidates have been previously characterized (6). In addition to $V$. nonalfalfae $(39,40)$, the nonindigenous weevil Eucryptorrhynchus brandti (Coleoptera: Curculionidea) $(17,46)$ and Fusarium oxysporum f. sp. perniciosum (Hepting) Toole (47) have also been proposed for control of Ailanthus in the eastern United States, though there are no data currently available regarding their field efficacy, nor has F. oxysporum f. sp. perniciosum been etiologically validated as a pathogen of Ailanthus.

Unintended geographic dispersal of potential biological controls beyond their intended range is of concern (33). The risk of unintentional spread of a biocontrol weevil, Oxyops vitiosa Pascoe, released to combat the paperbark tree (Melaleuca quinquenervia (Cav.) S. T. Blake) in Florida (33), appears to have resulted in its spread to New Providence Island, the Bahamas, Puerto Rico, and California, where it is thriving on landscape plantings of Melaleuca trees (33). Ultimately, reluctance toward using nonindigenous biocontrol agents is largely driven by economics. The need for effective biocontrol agents is often overshadowed by the significant investment of effort, time, and capital required to produce, register, and market the agents (11). Therefore, there is a strong impetus for development and utilization of controls that fall outside the registered pesticide model, including indigenous biocontrol agents (11) such as V. nonalfalfae on Ailanthus.

Indigenous fungal biocontrols have been used sporadically in the United States for nearly 50 years to manage native and exotic tree species. In Arkansas and south-central Oklahoma, persimmon wilt, caused by Acremonium diospyri (Crand.) W. Gams, has been used to control unwanted persimmon trees (Diospyros virginiana L.) in pastures (51). Similarly, in central Minnesota, oak wilt, caused by Ceratocystis fagacearum (Bretz) Hunt, has been previously tested as a silvicide for low-value oak trees (Quercus spp.) competing on sites better suited for pine (9). These two biocontrols have proven very effective at the local level and $A$. diospyri is still used to control persimmon (50). In New Brunswick, Canada, Chondrostereum purpureum (Fr.) Pouzar has also been used to combat "weed" red alder (Alnus rubra Bong.) and aspen (Populus spp. L.) (12). Neofusicoccum batangarum Begoude et al. was recently described to cause germination failure, wilting, dieback, and sapling mortality of the invasive Brazilian peppertree (Schinus terebinthifolius Raddi) in Florida (42). F. oxysporum f. sp. perniciosum (47) has proven lethal to exotic silk trees throughout the eastern United States (15) and could serve as an effective biocontrol of silk trees along highway corridors. More recently, a nonpathogenic strain of " $V$. alboatrum" being sold commercially under the name "Dutch Trig," has been used to potentially protect elm trees against Dutch elm disease (41).

The efficacy of $V$. nonalfalfae against Ailanthus compares favorably with other successful biocontrol programs. In South Africa, the nonindigenous, gall-forming rust fungus Uromy- cladium tepperianum (Sacc.) McAlpine has been used successfully since 1987 to combat the invasive Acacia saligna (Labill.) H. L. Wendl. (29,52,53). A 15-year study revealed an 87 to $98 \%$ reduction in Acacia density, from $\approx 50,000$ to $\approx 2,400$ stems/ha in five sites following inoculation of 50 trees/site (53). In the Florida Everglades, where the invasive Melaleuca tree has had catastrophic effects on freshwater habitats, implementation of insect biocontrols has resulted in a $70 \%$ reduction in mean stem densities from $\approx 27,500$ to 8,000 stems/ha during 1997 to 2005 (35). Similarly, $V$. nonalfalfae decreased Ailanthus stem densities from 1,500 canopy stems/ha to nearly zero at the leading edge of the epidemic within just 3 years. Ultimately, all inoculated Ailanthus overstory trees and adjacent noninoculated Ailanthus trees died from Verticillium wilt, and the pathogen continues to spread 7 to 10 years after inoculation.

Ailanthus sprouts generally survived for short periods within inoculated stands. The leading edge of diseased Ailanthus stands supported $>10$ times the number of Ailanthus sprouts compared with the center of the diseased stand and twice the number of Ailanthus outside the diseased area. These results indicate that vegetative sprouting may be the final reproductive strategy of Ailanthus in response to Verticillium wilt (39). Indeed, wilt symptoms on Ailanthus sprouts occurred only along the edge of the diseased area, where canopy symptoms had recently developed. Losses of second-generation spouts following mortality of Ailanthus parent trees likely accounts for an additional 10,000 to 15,000 diseased and dying Ailanthus. Our field observations indicate that surviving Ailanthus sprouts may live for several years, perhaps reaching $3 \mathrm{~m}$ in height, but eventually succumb to Verticillium wilt.

The incidence of native woody perennials in the regeneration subplots was not significantly different among subplot locations, suggesting that some native species persist among dying Ailanthus despite competition from other encroaching invasive species. This observation has been independently reported (14). Regardless of these findings, species richness is significantly reduced compared with sites without Ailanthus (30). We speculate that native species will flourish in the absence of Ailanthus as the stands grow and competition for resources and light intensifies.

All $V$. nonalfalfae isolates from Ailanthus and 18 additional isolates from nine other host species were members of the same MLST, MLST 1. Interestingly, variation in pathogenicity was observed within this single sequence type, which had not been observed in previous cross-pathogenicity testing among " $V$. alboatrum" isolates (5), thereby further validating host-adaption in Ailanthus isolates. Molecular characterization confirmed reclassification of numerous isolates from the morphologically identical $V$. albo-atrum to $V$. nonalfalfae, and supports the importance of clonal reproduction in $V$. nonalfalfae strains from North America and Europe. This study also documented previously unsampled diversity within $V$. nonalfalfae, because three isolates associated with lethal wilt of Actinidia chinensis in Chile appeared to be divergent from the known diversity of $V$. nonalfalfae (2) and represent a second MLST within $V$. nonalfalfae (MLST 2) (Fig. 6). Phylogenetic analysis also revealed that $\mathrm{VaCb} 241$, which was isolated from Catalpa bignonioides in Italy, appears to be the first report of $V$. alfalfae recovered from a presumably naturally infected non-lucerne host.

The use of $V$. nonalfalfae VnAa140 appears to be a highly effective tool to reduce problematic Ailanthus populations. Ailanthus was first introduced in Philadelphia nearly 230 years ago (23). Although best known as "a tree that grows in Brooklyn" (43), Ailanthus is common in major cities in at least 40 states throughout the United States $(1,23,27)$. In recent decades, Ailanthus has invaded many forests throughout the eastern United States, where it poses serious threats to native plant diversity. $V$. nonalfalfae causes mortality in Ailanthus and disseminates rapidly within Ailanthus stands of various ages and densities, 
presumably through infection from the rhizosphere (25) and via root grafts (26). In addition, integration of VnAa140 with the biocontrol weevil $E$. brandti may facilitate long-range dispersal of $V$. nonalfalfae (46). Similarly, the exotic ambrosia beetle Euwallacea validus (Coleoptera: Scolytinae) has been implicated in the passive dissemination of Verticillium $(24,38)$. On the basis of the results of the current study, as well as concurrent host range testing, root-graft transmission studies, and inoculation formulation studies, VnAa140 should be considered a viable biocontrol of Ailanthus altissima.

\section{ACKNOWLEDGMENTS}

This research was supported by funding from the United States Department of Agriculture Forest Service, Forest Health Technology Enterprise Team, Morgantown, WV. We thank E. Rosko, J. Ross, and C. Yeckley for their assistance in the field; as well as Pennsylvania State Game Commission, Pennsylvania Department of Conservation and Natural Resources, and Army Corps of Engineers for providing field study sites.

\section{LITURATURE CITED}

1. Aldrich, P. R., Briguglio, J. S., Kapadia, S. N. Morker, M. U., Rawal, A., Kalra, P. Huebner, C. D., and Greer, G. K. 2010. Genetic structure of the invasive tree Ailanthus altissima in the Eastern United State cities. J. Bot. Article ID 795735. Online publication. doi:10.1155/2010/ 795735

2. Auger J., Perez I., Fullerton R. A., and Esterio, M. 2009. First report of Verticillium wilt of Gold Kiwifruit, Actinidia chinensis cv. Hort 16A, caused by Verticillium albo-atrum in Chile. Plant Dis. 93:553.

3. Beach. 1929. Diseases of hardwoods. Ailanthus glandulosa. Plant Dis. Rep. Suppl. 67-74:372

4. Bhat, R. G., and Subbarao, K. V. 1999. Host range specificity in Verticillium dahliae. Phytopathology 89:1218-1225.

5. Correll, J. C., Gordon, T. R., and McCain, A. H. 1988. Vegetative compatibility and pathogenicity of Verticillium albo-atrum. Phytopathology 78:1017-1021.

6. Ding, J., Wu, Y., Zheng, H., Fu, W., Reardon, R., and Liu, M. 2006. Assessing potential biological control of the invasive plant, tree-ofheaven, Ailanthus altissima. Biocontrol Sci. Technol. 16:547-566.

7. Emmerich, T., Birmingham, M., and Daughtrey, M. 1998. Naturally occurring pathogen is killing Ailanthus (New York). Restor. Manage. Notes 16:223.

8. Feret, P. P. 1985. Ailanthus: Variation, cultivation, and frustration. J. Arbor. 11:361-368.

9. French, D. W., and Schroeder, D. B. 1969. Oak wilt fungus, Ceratocystis fagacearum, as a selective silvicide. For. Sci. 15:198-203.

10. Gravatt, G. F., and Clapper, R. B. 1932. Verticillium wilt of maple, Ailanthus, and elm. Plant Dis. Rep. 16:96-98.

11. Harman, G., Obergon, M. A., Samuels, G. J., and Lorito, M. 2010. Changing models of biocontrol in the developing and developed world. Plant Dis. 94:928-939.

12. Harper, G. J., Comeau, P. J., Hintz, W., Wall, R. E., Prasad, R., and Becker, E. M. 1999. Chondrostereum purpureum as a biological control agent in forest vegetation management. II: Efficacy on sitka alder and aspen in western Canada. Can. J. For. Res. 29:852-858.

13. Harrington, T. C., and Cobb, F. W. 1984. Verticillium albo-atrum on Ceanothus in a California forest. Plant Dis. 68:1012.

14. Harris, P. T., Cannon, G. H. Smith, N. E., and Muth, N. Z. 2013. Assessment of plant community restoration following tree-of-heaven (Ailanthus altissima) control by Verticillium albo-atrum. Biol. Invasions. Online publication. doi:10.1007/s10530-013-0430-2

15. Hepting, G. H. 1936. A destructive disease of the mimosa tree in the Carolinas. Plant Dis. Rep. 20:177-178.

16. Hepting, G. H. 1971. Diseases of forest and shade trees of the United States. U. S. Dep. Agric. For. Serv. Agric. Handb. No. 386. U.S. Government Printing Office, Washington, DC

17. Herrick, N. J., McAvoy, T. J., Snyder, A. L., Salom, S. M., and Kok, L. T. 2012. Host-range testing of Eucryptorrhynchus brandti (Coleoptera: Curculionidae), a candidate for biological control of tree-of-heaven, Ailanthus altissima Environ. Entomol. 41:118-124. http://dx.doi.org/ $10.1603 / \mathrm{EN} 11153$

18. Hibben, C. R. 1959. A new host for Verticillium albo-atrum Reinke \& Berth. Plant Dis. Rep. 43:1137.

19. Hiemstra, J., and Harris, D. 1998. Compendium of Verticillium Wilt in Tree Species. Ponsen and Looijen, Wageningen, The Netherlands.
20. Inderbitzin P., Bostock R. M., Davis R. M., Usami T., Platt H. W., and Subbarao K. V. 2011. Phylogenetics and taxonomy of the fungal vascular wilt pathogen Verticillium, with the descriptions of five new species. PLoS One 6:e28341. Online publication. doi:10.1371/journal.pone.0028341

21. Inderbitzin, P., Davis, R. M., Bostock, R. M., and Subbarao, K. V. 2011. The ascomycete Verticillium longisporum is a hybrid and a plant pathogen with an expanded host range. PLoS One. 6:e18260 Online publication. doi:10.1371/journal.pone.0018260

22. Inderbitzin, P., Davis, R. M., Bostock, R. M., and Subbarao, K.V. 2013. Identification and differentiation of Verticillium species and $V$. longisporum lineages by singleplex and multiplex PCR assays. PLoS One 8:e65990.

23. Kasson, M. T., Davis, M. D., and Davis, D. D. 2013. The Invasive Ailanthus altissima in Pennsylvania: a case study elucidating species introduction, migration, invasion, and growth patterns in the northeastern U.S. Northeast. Nat. 20(Monogr. 10):1-60.

24. Kasson' M. T., O’Donnell, K., Rooney, A. P., Sink, S., Ploetz, R. C., Ploetz, J. N., Konkol, J. L., Carrillo, D., Freeman, S., Mendel, Z., Smith, J. A., Black, A. W., Hulcr, J., Bateman, C., Stefkova, K., Campbell, P. R., Geering, A. D. W., Dann, E. K., Eskalen, A., Mohotti, K., Short, D. P. G., Aoki, T., Fenstermacher, K. A., Davis, D. D., and Geiser, D. M. 2013. An inordinate fondness for Fusarium: phylogenetic diversity of fusaria cultivated by ambrosia beetles in the genus Euwallacea on avocado and other plant hosts. Fungal Genet. Biol. 56:147-157. http://dx.doi.org/ 10.1016/j.fgb.2013.04.004

25. Klosterman, S. J., Atallah, Z. K., Vallad, G. E., Subbarao, K. N. 2009. Diversity, pathogenicity and control of Verticillium species. Annu. Rev. Phytopathol. 47:39-62.

26. Kowarik, I. 1995. Clonal growth in Ailanthus altissima on a natural site in West Virginia. J. Veg. Sci. 6:853-856.

27. McAvoy, T. J., Snyder, A. L., Johnson, N., Salom, S. M., and Kok, L. T. 2012. Road survey of the invasive tree-of-heaven (Ailanthus altissima) in Virginia. Inv. Plant Sci. Manage. 5:506-512. 2012.

28. Morehart, A. L., Donohue, F. M., III, and Melchior, G. L. 1980. Verticillium wilt of yellow poplar. Phytopathology 70:756-760.

29. Morris M. J. 1997. Impact of the gall-forming rust fungus Uromycladium tepperianum on the invasive tree Acacia saligna in South Africa. Biol. Control. 10:75-82

30. Motard, E., Muratet, A., Clair-Maczulajtys, D., and Machon, N. 2011. Does the invasive species Ailanthus altissima threaten floristic diversity of temperate peri-urban forests? C. R. Biol. 334:872-879. Online publication. doi:10.1016/j.crvi.2011.06.003

31. Nowak, D. J., Kuroda, M., and Crane, D. E. 2004. Tree mortality rates and tree population projections in Baltimore, MD, USA. Urban For. Urban Green. 2:139-147.

32. Pegg, G. F., and Brady, B. L. 2002. Verticillium Wilts. CAB International, Wallingford, UK.

33. Pratt, P. D., and Center, T. D. 2012. Biocontrol without borders: the unintended spread of introduced weed biological control agents. BioControl 57:319-329.

34. Qin, Q. M., Vallad, G. E., Wu, B. M., and Subbarao, K. V. 2006. Phylogenetic analyses of phytopathogenic isolates of Verticillium. Phytopathology 96:582-592.

35. Rayamajhi, M. B., Pratt, P. D., Van, T. K., and Center, T. D. 2009. Decline in exotic tree density facilitates increased plant diversity: the experience from Melaleuca quinquenervia invaded wetlands. Wetlands Ecol. Manage. 17:455-467.

36. Rebbeck, J., Malone, M. A., Short, D. P. G., Kasson, M. T., O’Neal, E. S., and Davis, D. D. 2013. First report of Verticillium wilt caused by Verticillium nonalfalfae on tree-of-heaven (Ailanthus altissima) in Ohio. Plant Dis. 97:999.

37. Robb J. 2007. Verticillium tolerance: Resistance, susceptibility or mutualism? Can. J. Bot. 85:903-910.

38. Schall, M. J. 2008. Verticillium wilt of Ailanthus altissima. Ph.D. dissertation, Pennsylvania State University, University Park.

39. Schall, M. J., and Davis, D. D. 2009. Ailanthus altissima wilt and mortality: Etiology. Plant Dis. 93:747-751.

40. Schall, M. J., and Davis, D. D. 2009. Verticillium wilt of Ailanthus altissima: Susceptibility of associated tree species. Plant Dis. 93:11581162.

41. Scheffer, R. J., Voeten, J. G. W. F., and Guries, R. P. 2008. Biological control of Dutch Elm Disease. Plant Dis. 92:192-200.

42. Shetty, K., Minnis, A., Rossman, A., and Jayachandran, K. 2011. The Brazilian peppertree seed-borne pathogen, Neofusicoccum batangarum, a potential biocontrol agent. Biol. Control 56:91-97. http://dx.doi.org/ 10.1016/j.biocontrol.2010.09.016

43. Smith, B. 1943. A Tree Grows in Brooklyn. Perennial Library-Harper and Row, New York.

44. Snyder, A. L., Kasson, M. T., Salom, S. M., Davis, D. D., Griffin, G. J., and Kok, L. T. 2013. First report of Verticillium wilt of Ailanthus 
altissima in Virginia caused by Verticillium nonalfalfae. Plant Dis. 97:837.

45. Snyder A. L., Salom, S. M., and Kok, L. T. 2014. Survey of Verticillium nonalfalfae (Plectosphaerellaceae) on tree-of-heaven in the southeastern United States. Biocontrol Sci. Technol. 24:303-314. doi:10.1080/ 09583157.2013.860426

46. Snyder, A. L. Salom, S. M., Kok, L. T., Griffin, G. J., and Davis, D. D. 2012. Assessing Eucryptorrhynchus brandti (Coleoptera: Curculionidae) as a potential carrier for Verticillium nonalfalfae (Phyllachorales) from infected Ailanthus altissima. Biocontrol Sci. Technol. 22:1005-1019.

47. Stipes, R. J. 2001. A tree that grows in Virginia. In: Shade Tree Wilt Diseases. C. L. Ash, ed. American Phytopathological Society, St. Paul, MN.

48. Talboys, P. W. 1960. A culture-medium aiding the identification of Verticillium albo-atrum and V. dahliae. Plant Pathol., 9:57-58. Online publication. doi:10.1111/j.1365-3059.1960.tb01147.x

49. Tamura K., Peterson, D., Peterson, N., Stecher, G., Nei, M., and Kumar, S. 2011. MEGA5: Molecular evolutionary genetics analysis using maximum likelihood, evolutionary distance, and maximum parsimony methods. Mol. Biol. Evol. Online publication. doi:10.1093/molbev/msr121

50. Templeton, G. E. 1987. Mycoherbicides-achievements, developments and prospects. Pages 489-497 in: Proc. 8th Aust. Weeds Conf. Sydney, Australia.

51. Wilson, C. L. 1965. Consideration of the use of persimmon wilt as a silvicide for weed persimmons. Plant Dis. Rep. 49:789-791

52. Wood, A. R. 2012. Uromycladium tepperianum (a gall-forming rust fungus) causes a sustained epidemic on the weed Acacia saligna in South Africa. Australas. Plant Pathol. 41:255-261. Online publication. doi:10.1007/s13313-012-0126-6

53. Wood, A. R., and Morris, A. J. 2007. Impact of the gall-forming rust fungus Uromycladium tepperianum on the invasive tree Acacia saligna in South Africa: 15 years of monitoring. Biol. Control 41:68-77.

54. Zwickl, D. J. 2006. Genetic algorithm approaches for the phylogenetic analysis of large biological sequence datasets under the maximum likelihood criterion. Ph.D. dissertation, The University of Texas, Austin. 